\title{
Reacting to the Workers' Revolt: The Lakehead and the Winnipeg General Strike
}

Michel S. Beaulieu

Perhaps no other event during the first half of the twentieth century shaped the nature and character of the Canadian left more than the workers' revolt that gripped the country between 1917 and 1925. During this eight-year period, the fundamental relationship between the state, workers, and capital was challenged. Most studies of the period have tended to focus solely on the events surrounding the Winnipeg General Strike-and it is doubtless that the strike in the windy city was influential_-yet labour struggles elsewhere also played a significant role in influencing the trajectory of the Canadian left. For example, David Bercuson and D.C. Masters both emphasize the six weeks of conflict in Winnipeg, but do not discuss either the underlying nature of the workers' revolt, or the often varied regional responses, ${ }^{1}$ and Masters argues somewhat erroneously that "strikes in Calgary, Edmonton, Vancouver, Port Arthur, and Toronto, helped to maintain morale." 2 More recently, Craig Heron and others concluded that while the revolt "was a cross-country phenomenon that emerged in similar ways across Canada... [it] nonetheless took a different course and faced different obstacles in each region." Significantly, the collection, while containing articles from the "five major regions," did not include works dealing with Newfoundland and Northern Ontario. ${ }^{4}$ Newfoundland may be a unique case because it was not a part of the country at the time, but the omission of Northern Ontario from a discussion of labour radicalism in Canada ignores one of the most vibrant and influential labour movements of the period.

Despite the region's importance in the turbulent histories of the One Big Union (OBU), Industrial Workers of the World (IWW), and Communist Party of Canada (CPC), scholars all too often neglect the Lakehead. Between 1917 and 1925, when mentioned at all, it is usually treated as an appendage to the Winnipeg situation in 1919 or western radicalism in general, and its contribution to the larger workers' revolt spreading across the country at the time is ignored. ${ }^{5}$ While the underlying motivation of events at the Lakehead in 1919 was symptomatic of the larger national trend, research indicates that the issue at hand for workers in the area was whether or not to support their Winnipeg comrades. Historians have long presumed that labour in Port Arthur and Fort William, known throughout the pre-War period as part of one of the most unsettled regions of the country, sup- 
ported the Winnipeg strikers without question. Yet no sympathy strike of any kind occurred. ${ }^{6}$ Considering the radical ideas and labour violence that characterized the pre-war socialist experience at the Lakehead and which marked the last years of the war, this apparent non-response in itself should be viewed as remarkable. It would be wrong to believe, however, that the absence of any labour action was synonymous with a lack of support for the Winnipeg strikers, or that the Lakehead was somehow immune from workers' unrest that existed across the country. This article tells the story of working-class politics at the Lakehead, Northwestern Ontario's metropole and a hotbed of labour radicalism, during the unrest of 1919.

Many socialists and trade unionists at the Lakehead whole-heartedly supported the workers in Winnipeg and believed in the goals of their comrades. However, while many of the barriers dividing the working class in the region began to break down in 1919, pre-existing divisions within the labour movement could not be overcome. The lack of dramatic Lakehead support in the form of strike action in 1919 stemmed from the region's distinctive class chemistry in the pre-war years, with previous ethnic-based violence and socialist/trade union tensions continuing to be influential. Few local people would have been oblivious to the risks of labour conflict, as experienced in the pre-war years. Secondly, what today can be labeled the centre-left-embodied in a solid local Labourist element-managed to mobilize much more effectively and appeal to a wider base of support. ${ }^{7}$ Further, the establishment of a Citizens' Committee in Port Arthur and a Citizens' League in Fort William by a variety of trade unionists and Lib-Lab supporters and backed by both city councils, successfully defused the very real threat of strike action even though workers' unrest remained high.

\section{The Lakehead Before 1919}

Combined, the twin cities of Port Arthur and Fort William were regional capitals. By the turn of the twentieth century, they were at the centre of the transshipment of goods into and out of both the North and Western Canada, and the export of the rapidly expanding wheat harvest and industrial sector depended upon them. Following this economic growth came a social transformation, as thousands of immigrants came to the Lakehead. The twin cities acquired all the accoutrements of North American modernity - a growing culture of consumption, an urban cityscape, and up-to-date utilities.

The economies of both cities were based on natural resources with the attendant workforce made up of skilled and unskilled workers and unions akin to those found in Western Canada, especially in the British Columbian forest industry. Manufacturing, however, also provided a small, but robust, centre for the surrounding region, and its workers-including labourers typical of larger seaportsshared in many respects the goals and desires of the eastern Canadian trade unions. The Lakehead in 1919 possessed the largest inland port in the world and 
its position as a central depot for the Canadian Pacific and Canadian National railways brought with it those from many of the running trades, not to mention the region's oldest unions such as the United Brotherhood of Railway Employees. ${ }^{8}$ While the region, in terms of the number of unions, was numerically diverse, its size and diversity worked against unity and coherence.

The labour movement at the Lakehead, as Anthony Rasporich has provocatively remarked, "was born divided." There were peculiarities to each city that precluded a unified labour movement and which went beyond the established differences between trade unions, the running trades, and socialist organizations. Some, Martin Robin in particular, have seen the roots of this division in a conflict between traditional craft unions and a growing socialist element more common among the unskilled workers and immigrants - one, that is, of "Labourism vs. Socialism." ${ }^{10}$ The first participated in politics either as part of the Liberal Party's "left-wing" or within "a semi-independent Liberal-Labour, or 'Lib-Lab, position." The second generated new movements and parties that sought to rally workers against such class alliances. ${ }^{11}$

Given the region's geography and economy, most national unions were represented in each city, although their strength on the various labour councils differed. However, until 1902, organized labour was practically non-existent. It was not until American Federation of Labor organizer Harry Bryan came to the Lakehead in that year that organizational activity began in earnest in a number of trades. As a union man he could count his success by the number of unions chartered-as many, some claim, as 22. Less disputed is his role in establishing a Central Labor Union (CLU) comprised of union members from both Port Arthur and Fort William. ${ }^{12}$ The CLU became the first expression of political voice for workers when its loose coalition of unions backing L.L. Peltier as a labour candidate emerged before the federal election. ${ }^{13}$

However, Bryan was not alone in his attempts to organize workers. The Lakehead was a centre for non-British immigration during the first two decades of the twentieth century as Finns, Ukrainians, and Italians arrived by the thousands to the region. Most of these immigrants did not have common cause with the existing Anglo-dominated trade unions organized under the AFL and later the Trades and Labour Congress of Canada (TLC). The TLC in fact advertised itself locally as the only organization in the region capable of protecting workers from "cheap, foreign-born labour." 14 As a result, many newer immigrants formed their own workers' associations, based on principles that had guided them in their home countries.

The ongoing economic and social rivalry between Port Arthur and Fort William were reflected in divisions within the labour movement. As the Central Labor organization - established in 1902-began to fall apart, it resulted in the creation of city-specific labour councils in Port Arthur in 1907 and then in Fort William the following year. Added to the classic tension between skilled trades and 
other workers was the question of ethnic difference. The Finns in particular in Port Arthur and the Italians and Ukrainians in Fort William were a challenge to the Lakehead's labour organizations which were, until then, characterized by a tradebased labour aristocracy made up of British-born individuals. Ethnic tensions, therefore, were a major factor during episodes of labour unrest in 1909, 1912, and 1916, events which saw Anglo-Saxon trade unionists pitted against larg ely unskilled immigrant workers. These events and others caught the attention of national media for both their frequency and violence. The 1909 strike by railway workers, for instance was described by the Industrial Banner as "probably the bloodiest labor riot ever in Canada," and, given the relative size of the workforce at the Lakehead, it certainly was. ${ }^{15}$

Long blocked from political involvement and frustrated by the English orientation of trade unions, many immigrant workers were pulled to the various socialist organizations operating in Canada. Finnish workers, for instance, established a branch of the Socialist Party of Canada (SPC) in Port Arthur in 1906. ${ }^{16}$ The SPC, and later the Social Democratic Party of Canada, provided a natural home for immigrants who were looking to take a more active political role within Canada. A participation in socialist organizations also proved to be a unifying factor for many workers in the region as they were both popular amongst the immigrant workers and remained "an ideal for progressive-minded labour leaders, as did the goal of organizing the unskilled." ${ }^{\prime 17}$ Harry Bryan and others began to increasingly work together to put forth provincial and federal candidates in elections, even if Anglo-Saxon workers remained a minority in these and other socialist organizations and often had to compete against other workers' candidates until after the First World War in the region.

By 1914, however, the notion that socialists and violence were synonymous had been implanted within the minds of many in the community. So too had the role of immigrants within socialist organizations and their role in radicalizing local union activities. The limitations and strengths of socialism at the Lakehead revolved around both issues of ethnicity and ideology. Coming to grips with these two factors had allowed Harry Bryan and others to successfully mobilize workers to protest their conditions and had resulted at times in real municipal electoral successes. It also, though, drew the attention and ire of civic, provincial, and federal governments increasingly concerned with what they perceived as radicalism brewing in the region.

\section{Responding to Bolshevism}

For workers at the Lakehead, the First World War merely proved to be a further "embittering experience," much as it would be for their brothers and sisters across the country. ${ }^{18}$ Its conclusion, coupled with the events in Russia in October 1917, led to a "sense of grievance" amongst many which provided an opening for a 
more radical form of social and political protest that would successfully challenge the power of the Trades and Labour Congress of Canada. ${ }^{19}$ In fact, the Lakehead's response to Winnipeg 1919 can first be understood in part by first looking at the final months of the Great War.

The decision by Vladimir Il'ich Lenin and his government to pull out of the First World War on 23 February 1918, the subsequent collapse of the Eastern front, and the movement of tens of thousands of German and Austrian troops to the Western Front, greatly influenced the actual conflict and the perception of the Bolsheviks within Canada. Ostensibly, hundreds of Canadian and allied troops were sent as part of a strategy for winning the war by reopening the Eastern Front. These troops, though, did not leave Russia following the end of the war. As Roy MacLaren remarks, propelled in part by a desire to keep wartime factories active and to demonstrate Canada's new international status, the government decided to keep the troops in Russia to give "the anti-Bolsheviks time to reorganize and to recruit new forces with which to eliminate what [Winston Churchill] later called the "foul baboonery of Bolshevism."' Wh While the Allied intervention ultimately failed, newspaper cove rage in Canada increasingly port rayed the postwar Bolsheviks much in the same guise they had applied to the Germans and Austrians during the war.

Just as the Dominion government announced that Canadian troops would be leaving Siberia, newspapers increasingly ran articles describing Bolshevism as the new threat. ${ }^{21}$ Leading socialists in the United States, such as Eugene Debs, were targeted, and the connection between them and figures in Russia was the subject of many articles and editorials. Events in Russia, and the spread of Bolshevism in particular, became a consistent topic in local newspapers and a growing issue between the local trades and labour councils and the region's socialists. Authorities ranging in diversity from the nineteenth-century philosopher Thomas Carlyle (who had said, "no revolution ever rises above the intellects of those that make it") ${ }^{22}$ to contemporary part-time analysts of "Bolshevism" who viewed it as the hobby of the "amateur woild-mender" Revolution. Bolsheviks were all-purpose villains, blamed for a host of ills, such as the dissent then sweeping the mines of Western Canada. ${ }^{24}$

Closer to home, there were, from the mainstream perspective, even more alarming indications of a growing Bolshevik presence in the region. ${ }^{25}$ While socialists of all hues were targeted, special attention was reserved for those who belonged to immigrant communities. For their heavy involvement in the formation of socialist organizations within the region, the brunt of this attention at the Lakehead and across the country was reserved for Russians, Ukrainians, and Finns. It did not help local labour that it was the Industrial Workers of the World and the Finns that took the lead in supporting the Russian Revolution at the Lakehead as it had profoundly influenced political developments in Finland. The overthrow of the Tsar, in particular, was very popular amongst local Finns since for many, Russia 
was seen as the Finns' ancient adversary.

Sensational headlines such as "Lenine [sic] Would Release Million Hun Prisoners" became the norm. ${ }^{26}$ Corporate interests watched the situation with concern. The Mutual Elevator Company of Fort William, for example, asked the city council for increased protection ${ }^{27}$-yet the issue still came to a head with a strike of about 1,100 elevator employees in both Port Arthur and Fort William over wages, hours, and working conditions. The strike essentially ground all activity in both cities to a halt as the ports could no longer take incoming ships and the CPR became congested as grain coming from the West could no longer be unloaded and the regions' war production unable to move east. ${ }^{28}$

How was this impressive propaganda offensive received in the Lakehead? For the most part, on the available evidence, many Lakehead workers seem to have been ambivalent about it. Within the cities of Port Arthur and Fort William, most of the major unions either were in the midst of negotiations or had just reached some form of agreement with their employers. For the first time in the history of the Lakehead, the 175 men working for the Freight Sheds in Port Arthur were English-speaking - a harbinger, some hoped, of a new class and ethnic atmosphere in the region. A reporter from the Port Arthur Daily News-Chronicle contentedly observed that in 1919 there existed a "difference in the demeanour" of these men when they were contrasted with the "foreigner." ${ }^{29}$

In the months just prior to the unrest in Winnipeg, the Dominion government quickly agreed to Fort William and Rainy River Unionist MP Robert Manion's request for the establishment in mid-April of a detachment of 20 Royal North West Mounted Police in Fort William to "avert the possible rise of "Bolshevism and revolution" and to counteract the "foreign" and "radical" element present in the local workforce. ${ }^{30}$ Manion and others believed that when the Winnipeg municipal Electrical Workers took initiative and began striking on 1 May 1919, with calls for a general strike both locally and nationally, that the Lakehead contained a revolutionary potential which, given the region's strategic significance in the grain export trade and its geographical centrality, had the potential of overshadowing even that of Winnipeg itself. Port Arthur and Kenora Unionist MP Francis Henry Keefer clearly felt there was a clear and present danger in the region when he argued that the entire force should be increased by 5,000 as "dangerous days were ahead of Canada" and "there were breeding places of revolution" that needed to be dealt with. ${ }^{31}$ As the editor of the Port Arthur Daily News Chronicle wrote the day before the Winnipeg General Strike began, "there is an element in this country consisting largely of aliens, which would welcome an opportunity to start a revolution." This group, he suggested, was only waiting for the right conditions. The present unrest and increasing cost of living, "this rich soil for the alien agitator, striving for a repeat of the Russian revolution," could be removedeither by timely reforms or by the exercise of armed force, the latter option emphasized by Keefer. ${ }^{32}$ 
Another solution, advocated by officials in Port Arthur and Fort William, was to combine increased police presence with the deportation of "alien enemies." Both city councils endorsed a letter sent by the Great War Veterans' Association of Winnipeg to its local branches calling upon the "government to enact legislation to deport all undesirable aliens, to take aggressive steps to educate foreigners in English, to place a strict censorship on immigrations, and to keep foreigners under close observation." ${ }^{33}$ Perhaps telling, despite economic difficulties in some sectors of the local economy, non-Anglo workers without work were deemed to be in such a situation "by choice, but not of necessity." Frederick Urry, a prominent social and moral reformer and the symbol of Lakehead leftism before the war, led the more moderate elements. He criticized the closed shop and deplored the impact of outside agitators. ${ }^{34}$

Urry was an admirer of the British labour movement. Before his arrival in Canada, he had been a member of the British Independent Labour Party. Tellingly, upon his arrival in Port Arthur in 1906, he commented on the "lamentable state of trade unionism" in the city. ${ }^{35}$ Between his arrival and death in October 1927, Urry would play a prominent role in all aspects of the Anglo trade union movement, continually working, one biography argues, "for a community of interests between Christians, socialists and trade unionists." ${ }^{36}$ Conscious of the relationship needed between trade unionists, the social gospel, socialism, and local politics, Urry had before the war launched himself more directly than previous socialists into the ideological debate facing the left in the first two decades of the twentieth century. A social-gospeller, in 1908, he became the regional representative to the Presbyterian Church of Canada's Board of Social and Moral Reform and later its representative to Canadian labour. ${ }^{37}$ Urry was also one of three from Port Arthur who attended the founding of the SPC's Ontario section as official delegates and attended the TLC's annual meeting in Halifax on behalf of the Port Arthur Trades and Labour Council. As Morrison justifiably suggests, "his participation in these conferences symbolizes his attempt to use and unite trade unionism, socialism and the social gospel" to further his vision of a "co-operative commonwealth based on social and class harmony." Of note, the meeting denounced bolshevism and the events in Russia. ${ }^{38}$

However, Urry's position met with hostility from some in the region. No incident better illustrates this than the founding meeting of the Port Arthur Trades and Labour Council in 1908. No representatives from non-Anglo dominated organizations or unions were invited and the Finnish branch of the Socialist Party of Canada was particularly excluded. Representing the Fort William Trades and Labour Council and a member of the International Typographical Union was Leo T. English. Speaking on behalf of the SPC, English expressed his disgust, remarking, "I have come to the meeting hoping to hear a workingman's story, but instead I have heard a couple of politicians and a couple of ministers." ${ }^{39}$ 


\section{Winnipeg and the Lakehead's Reaction}

Nowhere was the growing suspicion of Bolshevism and the threat of growing revolutionary tendencies within the Canadian working class more apparent than in the Winnipeg General Strike. Even before the onset of the strike, both the Port Arthur and Fort William newspapers frequently contained articles culled from the national news services about the growing unrest in Winnipeg. Occasionally, it was reported by some unnamed resident that a fellow worker passing through the twin cities had commented on the deplorable conditions many in Winnipeg faced. News of the possibility of some form of general strike in Winnipeg reached the Lakehead on 7 May 1919.40 Between 7 and 14 May newspapers contained daily reports of the activities of the Winnipeg Trades and Labour Council and, as early as 9 May, articles on the "inevitability" of a general strike. ${ }^{41}$ Residents of the Lakehead awoke on 15 May to news that over 27,000 unionists had left their jobs to enjoy a "Bolshie' Holiday." 42 The Fort William Daily Times-Journal described Winnipeg on the second day of the strike as being "Primitive as [an] Indian Village," a city held hostage by autocratic strike leaders and forcibly isolated from the wider world. Others discerned "Soviet rule" in a Winnipeg that had fallen under the rule of "Prussian war lords" and been transformed from a prosperous and busy city into a "non-producer." In such analyses, both the strike committee and the Winnipeg elite were blamed for bringing the city to a standstill. ${ }^{43}$

The Lakehead press thus orchestrated a 'centrist response' to Winnipeg that seemingly found echo in the local labour movement. Unions and labour councils did not rise up in defence of Winnipeg. Even reports of trains carrying troops to the city aroused no response. ${ }^{44}$ As the Winnipeg conflict entered its most dramatic stage, a labour meeting in Fort William featuring Dominion Labour Party activists, including local labour-supported alderman A.H. Dennis, focused on reassuring the public that "[the] people, not a select few, must govern here." ${ }^{45}$ The established craft unions at the Lakehead generally saw little in Winnipeg to inspire them. They had traditionally politically supported Independent Labour, although one that was closely aligned with the Liberals in both cities. These unions also tended to benefit, and support, discriminatory practices against non-Anglo workers, and stood to lose much if they supported any upsurge of radicalism.

At the same time, other workers, inspired by events in Winnipeg and restless with the leadership of such craft unionists, began to hold separate meetings to hear presentations by delegates from the General Strike committee and formulate tactics to have their grievances heard and acted upon. While the Fort William and Port Arthur Trades and Labour Councils continued to debate the issue of supporting the Winnipeg strikers (with the hope that the Winnipeg "situation" would be over before they needed to make a decision), a meeting was held in the Corona Theatre in Fort William. ${ }^{46}$ The meeting was arranged to hear a delegate from the Winnipeg Strike committee who had accompanied the Finnish socialist, Wobbly, 
and future prominent member of the Communist Party of Canada, A.T. Hill back to the Lakehead following his trip to meet the strike leaders. ${ }^{47}$ The unnamed delegate spoke to a full house, and received an encouraging response; and with the further support of the "founder" of the local labour movement, Harry Bryan, the assembled workers passed resolutions favouring an immediate general strike which brought the issue to the urgent attention of the trades and labour councils in the twin cities. ${ }^{48}$

"We have nothing to give out for publication" was the comment provided to local newspapers by Fred Moore, secretary of the Fort William Trades and Labour Council, following a raucous meeting at the Finnish Labour Temple in Port Arthur to discuss the resolutions made at the previous night's meeting chaired by Harry Bryan. ${ }^{49}$ In fact, while the council agreed with the complaints made by the Winnipeg strike committee, its actions were not condoned. The resolution put forward and passed called for action only in the event of "unfair methods or [the] use of the military." ${ }^{\prime 50}$ Something similar had occurred two days earlier when trade unionists in Port Arthur met to discuss the issue and to listen to a speaker from Winnipeg. A.F. Manchee, secretary of the Port Arthur Trades and Labour Council, reported that the meeting, open only to those carrying union cards, had been attended by over 1,000 trade unionists. A resolution had been passed at this meeting and a letter forwarded to the Winnipeg strike committee pledging their "full moral support for their brothers." Speculation abounded following the announcement of the resolution. Some believed this meant that a sympathy strike was imminent in Port Arthur, while others connected to various unions scoffed at the idea and reminded residents that each union must take a vote on such a resolution. $^{51}$

These meetings, though, did not go unnoticed by federal, provincial, and local officials. Civic officials were watching the events in Winnipeg closely and, with the strike of Kenora express handlers, with increasing concern. ${ }^{52}$ Despite the tepid resolutions put forward by the trades and labour councils, officials were cognizant of the more radical elements at the Lakehead, the large number of "Finns" and other "foreigners" present at both meetings, and the role of Bryan and others in the unrest that had rocked the twin cities before the First World War. ${ }^{53}$ Some local leaders also shared this worry. They tried to downplay the participation of non-Anglos fearing that this would discredit the efforts of organized labour. Even though the meeting at the Corona was held in opposition to the Fort William Trades and Labour Council, Fred Moore, for instance, took exception to statements by local papers that the majority of those in attendance were Finnish and Austrian. He argued that such comments were part of a "scheme seemingly practiced all over the country" to "heap upon its [organized labour's] activities the stigma of non-patriotism." ${ }^{54}$ Yet, government officials in both cities believed that many immigrant workers were unpatriotic. Such fears were heightened when the Lakehead press began to broadcast the rumour that the IWW had orchestrated the 
Winnipeg Strike. ${ }^{55}$ As news of the growing turmoil arrived at the Lakehead, municipal, provincial, and federal officials began to worry about what effect the unrest in Winnipeg would have in the twin cities. ${ }^{56}$ Unions currently involved in contract negotiations distanced themselves from the radicalism thought to be sweeping Winnipeg. ${ }^{57}$

When the residents of Port Arthur awoke on the morning of 19 May to find that over 1,300 workers from the Lakehead's biggest industry, the Port Arthur Ship Building Company, had gone on strike, they were quickly assured by both the unions and the company that the dispute had been caused by the suspension of ongoing negotiations. It was not a sympathy strike. ${ }^{58}$ Representatives from the City of Port Arthur, the Board of Trade, the Trades and Labour Council, and those unions involved all took part in the negotiations in an attempt to defuse the situation. ${ }^{59}$ As the boiler makers' union and shipbuilders' union's representative, J. Grant, stated, "the best of feelings exists between the company and the men, and the men don't wish to work for a better company, but we have got to get the high cost of living down, or else we have got to get sufficient wages to enable us to live." $" 00$

The striking unions in Port Arthur emphasized that their primary grievance was with the federal government's stance toward a skyrocketing cost of living, and not with the local company. Local merchants and businessmen shared this sentiment. Frederick Urry once more served as a spokesperson for this centrist perspective. ${ }^{61}$ Yet, while union representatives did have the Winnipeg strike on their mind, the possibility of a nation-wide general strike and the government fear of such an event was a tool to be used for their own immediate gains. ${ }^{62}$ The strike ended two days later with the workers receiving all of their demands. ${ }^{63}$ When the Fort William coal dockworkers did go on strike, both sides took care to distance their local issues from the situation in Winnipeg. This strike was in no sense a 'sympathetic strike' designed to emulate the Winnipeg model. ${ }^{64}$

To deal with complaints over the increasingly high cost of living, city councils in both Port Arthur and Fort William held special meetings to discuss the issue following the order-in-council rescinding the ban on the power municipalities held "over those making excess profits." Fort William quickly established a Fair Price Inquiry Commission comprised of three representative taxpayers with the power to summon witnesses and to obtain court proceedings. The committee reported their findings to the Fort William City Council which, depending upon the findings, would then appoint another commission composed of the senior district Judge, a representative selected by labour, and a representative of the "commercial trades." Their report was binding and forwarded with the council's full endorsement to the Minster of Labour. ${ }^{65}$ However, as the editor of the Port Arthur Daily News Chronicle reported, the council by its actions "washed its hands of any responsibility regarding the high cost of living" and instead demanded that the Dominion and Provincial Government not shirk their responsibility 
and "get at the 'fountain head' of the high cost of living [or] resign."

By 29 May, rumours reached Ottawa that workers in Fort William and Port Arthur were meeting to decide whether or not to start a general sympathy strike. ${ }^{99}$ In a telegram to Fort William Mayor and ILP member, Harvey Murphy, the Dominion Minister of Labour, G. D. Robertson, attempted to assure officials in the twin cities that the Winnipeg strikers "deserve no sympathy from organized labour outside." Robertson further informed Murphy that, under the pretext of supporting the Metal Trades Council and the right to collective bargaining, the strike was actually "intended to be a blow at international trade unions" and to rally support nationally for the One Big Union movement. The goal of the strikers and the union, he argued, was "the probable intention of seeking to overthrow constitutional affairs and governments both as to Federal, Provincial, and Municipal affairs." As for the "Emissaries sent East and West this week for the purpose of obtaining sympathetic action in other cities," Robertson believed that they were "wholly without justification as the citizens of points outside Winnipeg are in no way responsible for the dispute here and certainly should not be inconvenienced as a result of this local conflict." ${ }^{\prime 67}$

Upon Robertson's request, Murphy forwarded the telegram to the local Trades and Labour Councils. He promised to "seriously consider" their actions and even suggested that he had received reports indicating that the Winnipeg situation "is about to be amicably settled by arbitration." ${ }^{68}$ Murphy, however, was well aware that trade unionists from both cities had already met independently at the Port Arthur Finnish Labour Temple, and had voted to tentatively support the Winnipeg strikers under certain conditions. In addition, he was also aware of the gathering held at the Corona Theatre in Fort William chaired by Harry Bryan that unanimously passed a resolution in favour of a sympathy strike. ${ }^{69}$ Murphy's letter to the Joint Trades and Labour Council's meeting on the afternoon of 29 May, newspapers in both cities reported, was returned and he along with Port Arthur's mayor were informed that a resolution on the situation in Winnipeg had been passed. Its content, however, was not disclosed either to the local media or to civic officials.

The editor of the Fort William Daily Times-Journal, however, cautioned workers in both Port Arthur and Fort William to avoid being dragged by "the chariot wheels of Winnipeg" into a general strike. He reminded them that the "practiced socialist speaker" could easily portray the "triumphant victory of the workers and total extinction of capitalists." Much less clear, according to the newspaper, were the ways in which any such triumph might be accomplished. "When the battle is over and the Winnipeg labor men have either lost or won or reached a settlement of some kind, they will be too busy repairing the ravages that weeks of enforced idleness have made in their own conditions to pay much attention to the workers of Fort William and Port Arthur." Workers, the editor suggested, would be "knocking the props [out] from under their own city." He reminded them that 
they risked giving Winnipeg, the twin cities' economic rival, an advantage. ${ }^{70}$

\section{The Citizen's Committees}

Just as the more radical elements of the Lakehead's working class were mobilizing in opposition to the status quo, so too were more moderate workers representing trade unions and professional and salaried workers mobilizing in its defence. Upset with the Trades and Labour Councils' decision to oppose, even tacitly, government intervention in the Winnipeg strike and also by the government's handling of the strike, centrists formed two new organizations, the Canadian Citizens' League in Fort William and the Citizens' Committee in Port Arthur, both in late May. ${ }^{71}$

The Canadian Citizens' League was envisioned as a pan-national organization headquartered in Fort William. Headed by Frederick Urry, the organization "promoted moderation and class co-operation," and publicly denounced the Winnipeg General Strike as a "Bolshevik Plot."”2 Its manifesto upheld the rights of the middle class, which, it argued, "was ground between the upper and nether mill-stone." Central to its worldview was the concept that "a properly constituted state or city" could never exist without "capital, the so-called middle-class, or labor." To achieve class harmony, it believed, five objectives needed to be fulfilled:

1) To obtain the removal of unfair burdens imposed on all the classes;

2) To enable citizens, by united co-operation, to protect their interests when threatened by Government or industrial tyranny;

3) To scrutinize and watch legislation to ensure that all or any citizens are not unjustly exploited, and to secure amendments to the law where the interests of the citizens generally are unfairly dealt with;

4) To co-operate in the advancement of industry, both production, dis tribution and consumption, and to eradicate uneconomic practices;

5) To support by Every Means in Its Power Constituted Authority and to uphold the Present System in Canada of Constitutional Government.

The manifesto was designed to appeal as broadly as possible to centrist opinion in Fort William. In an apparent bid to win the support of newly enfranchised women, it even suggested that the equality of men and women would be a guiding principle of the new organization. ${ }^{73}$

Although the Canadian Citizens' League enjoyed the support of the local press, another twin cities organization was the subject of much debate. "A storm of protest" resulted when the Port Arthur City Council passed a resolution at a special meeting supporting and legitimizing the powers of a Citizens' Committee. Recognizing the "loyalty and discretion of the citizen's [sic] committee," the resolution requested that it "take all reasonable steps which may seem necessary to them to preserve the public peace, and that the city council will defray all expens- 
es." The Port Arthur City Council also declared that it would ensure that the public utilities commission and special police constables would be made available to them (and presumably under their control) in case of a general strike or as the citizens' committee deemed necessary. ${ }^{74}$ The major difference between the citizen's committee in Port Arthur and the one in Winnipeg-one not lost on the Port Arthur City Council—was the fact that in Port Arthur they could claim that it had arisen from civil society.

Those in support of the resolution, such as Aldermen F. Duncan Roberts and L. J.B. Bolduc, argued that as the people of Port Arthur in fact owned the utilities (as a result of decisions made in the 1902 election), and that they therefore enjoyed the collective right to ensure their protection. Not all councilors, however, were in favor of the resolution. Some discerned startling similarities between the Port Arthur Citizens' Committee and the "Citizens Committee of 1000" that had arisen in opposition to the Winnipeg General Strike. The editor of the Daily Times Journal, for example, wrote that "any outside organization [which] desired to help in this work should be welcomed, but, on the other hand, no outside organization should be allowed to even make the 'pretense' of running the city." 75

Leading the opposition in Port Arthur was Alderman Sid Wilson, a former prominent local member of the Social Democratic Party of Canada. An officer of the $94^{\text {th }}$ Battalion recently returned from Winnipeg and the president of the Port Arthur Branch of the Great War Veterans Association, he launched into a tirade as soon as the motion was put forward. He voiced his displeasure with the local newspapers for publishing "such stuff" and for their coverage of the Winnipeg General Strike, and noted, "In Winnipeg there was a great objection to a certain body of citizens trying to run the city apart from the city council." In Winnipeg, the Committee of 1,000 had taken power against the wishes of the city council. In Port Arthur, the City Council was unbelievably cooperating in its own demise- even to the point of funding its rival! $!^{76}$ Alderman Dunbar agreed. By endorsing the "self-appointed" citizens' committee, the Council itself was admitting that it was "not capable of coping with the situation [a general strike] should it occur." Endorsement of the resolution, he argued, would only aggravate the situation at the Lakehead and undermine municipal authority. When the announcement was made that the resolution had passed, Alderman Young, who had joined Dunbar and Wilson as the only councilors opposed to the scheme, turned to the members of the Citizens' Committee present and cried out: "Now go ahead and run the city. Let us hand it over."'77

The controversy surrounding the Citizens' Committee did not end with the passage of the resolution. Distancing the labour council from any possible action taken by the more radical unions, Dunbar argued that it was the unions that would make such a decision and it was from them that information would have to be requested. Alderman Bolduc, one of the chief supporters of the Citizens' Committee, scoffed at Dunbar's suggestion and found it odd that the TLC, which 
he viewed as the centre of the existing unrest, was unable to give information "to put a stop to the destruction of organized government." Citizens' League's objectives became the content for editorials in the Fort William newspaper, the very possibility of a sympathy strike had an immediate impact on the Lakehead. Would "the sanest section of labour" continue to prevail? Residents were divided between those who feared the local consequences of a sympathetic strike and those who identified with the Winnipeggers' demands. Were they reasonable responses to the high cost of living and the autocracy of the federal government? Alternatively, did foreign conspirators acting out of ulterior motives

orchestrate

them? $?^{79}$

\section{Growing Divisions}

The evidence of a growing division within the local Trades and Labour Councils did little to alleviate this concern. Many of the long established Anglo-dominated unions had refused to participate in the sympathy strike vote that occurred at the meeting chaired by Harry Bryan at the Corona Theatre in Fort William. This included members of the Brotherhood of Locomotive Engineers, the Brotherhood of Locomotive Firemen and Engineers, the Order of Railway Conductors, and the Brotherhood of Railway Trainmen. Nationally, these groups and other running trades had long spurned involvement in the TLC although locally they had formed an integral component of labour councils. In fact, these unions held their own separate meeting after which they called upon officials at all levels of government to immediately intervene in Winnipeg to prevent "a nationwide catastrophe." ${ }^{80}$ While government authorities feared their participation at the Lakehead as they did throughout western Canada, in Port Arthur and Fort William they had sided with labour and were in favour of the citizen's committees. ${ }^{81}$ The decision of many civic workers in both cities to not participate as well was duplicated elsewhere across the country. In Calgary, for example, civic workers organized under the Calgary Federation of Civic Employees "opted," according to Tom Mitchell and James Naylor, "not to wager their newly achieved collective agreement." $"{ }^{2}$

While the vote itself may not explain the lack of a strike at the Lakehead, the turmoil surrounding the vote did serve to negate any chance at solidarity amongst all workers and, by 4 June, newspapers in both cities began to report that unions "appear to be giving up the idea of quitting their work." "83 Even interest in the Citizens' League in Port Arthur, having initially been positive, declined within days of its formation. ${ }^{84}$ In fact, despite the grandiose claims found in its manifesto, the Citizens' League appears to have concerned itself more with combining pleasure with business and taking "the day off for a Picnic." Nothing was done, for example, when the Grand Trunk decided to close its freight sheds in Fort 
William and reduce many Ukrainian, Italian, and Finnish men to unemployment. ${ }^{85}$ Yet, however limited the League's practical effects may have been, it exerted an important symbolic influence. In her brief assessment of the Lakehead's response, Jean Morrison argues that the formation of the organization and the participation of many leading labour figures in it was one of the major reasons wide-scale sympathy strikes never occurred at the Lakehead. ${ }^{86}$ Existing evidence supports this claim. Following the establishment of these two citizens' organizations, those unions and organizations that had participated in the vote in favour of a sympathy strike took a softer tone. While the announcement on 4 June 1919 that the members of the Joint Trades and Labour Council had voted in favour of a strike mandate did provoke a response from officials in both cities, the growing factionalism within the working class essentially made the motion toothless, despite the fact that a clear majority of those present favoured striking. ${ }^{87}$

In Fort William, the timing of the establishment of the league and the participation of Frederick Urry directly influenced both the outcome and the credibility of the sympathy strike vote. While a number of unions went on record supporting the voting proposal, others declined to participate. The public was not informed, however, which unions had taken what position. ${ }^{88}$ However, records of Finnish socialists reveals that the English dominated unions sided against those with higher percentages of Finns and those lead by individuals such as Harry Bryan, that were more openly socialist. ${ }^{89}$

A day after the announcement that workers had voted in favour of supporting the Winnipeg Strikers, representatives from the Fort William Trades and Labour Council agreed that their members would delay any strike activity and attend a mass meeting brokered by the Fort William Great War Veterans' Association (GWVA). Interestingly, the GWVA and the Fort William Trades and Labour Council had been involved in separate meetings since 22 May following the strike of dockworkers over the high cost of living. ${ }^{90}$ The GWVA was also cognizant of the recent decision of their Vancouver brothers to oppose the Winnipeg strike. The growing tensions between the Winnipeg GWVA and strikers in that city spurred the Fort William branch to approach the Joint Trades and Labour Council to ask for a delay in any strike activity until a public meeting among veterans, civic officials, labour leaders, and citizens could be held. The GWVA also asked and received clarification "upon what lines it [the strike] would be conducted." In contrast to the Winnipeg strikers, representatives of the Joint Trades and Labour Council "strike committee" responded that if a strike were called, workers would still recognize the mayors of both cities as "the fountain of authority" in their respective cities. ${ }^{91}$

Perhaps the most important item acquiesced to by the strike committee-comprised mainly of Anglo trade unionists and supporters of the Independent Labour Party — was the GWVA's request that any decision to strike be delayed until a response was received from Dominion and Provincial represen- 
tatives to a resolution demanding immediate government action on both the situation in Winnipeg and on the high cost of living. Essentially, the resolution demanded that Mayor Murphy of Fort William contact all regional, federal, and provincial officials. These men should then deal with the Winnipeg situation and the growing cost of living or resign and submit such issues to the electorate. "There would be no trouble in Fort William," J.R. Pattison suggested, if "detectives and scab clerks were kept out." Representatives from the trade unions and labour party described the workers at the Lakehead as preferring to work with government officials. They were British "subjects" and "in full agreement with the British Constitution which they consider to be the greatest constitution on earth." Trouble could be averted at the Lakehead, such centrists argued. Workers had successfully negotiated with their employers in both cities. A Winnipeg model of destructive polarization need not be followed in the region. ${ }^{92}$

The June meeting of unions did result in a resolution recognizing the lack of workers' voices in determining working conditions and the role of the Dominion government in taking action. It called upon the government to legislate collective bargaining and to grant workers a living wage. Finally, it also demanded that action occur within 48 hours or the government resign and submit the question to the electorate. As the capacity crowd was comprised of fifty percent workers and the balance comprised of those unconnected to the labour movement and members of the newly-formed Canadian Citizens' Committee, the resolution passed without any difficulty. While, on the one hand, such an outcome could be viewed as an acknowledgement of the strike committee's concerns, and they themselves later suggested as much, the content of the resolution also reflected the general disgust felt towards the Conservative efforts to quell the Winnipeg conflict. $^{93}$ The resolution also allowed both the strike committee and the civic officials to save face.

It should not be assumed that each of the twin cities agreed with how the other responded to the growing tensions in the region. Differences in the composition of the working class in each city and the exclusion of Finns and other non-English workers in much of the Port Arthur meetings provided for differences. For example, those who attended the Fort William meeting mocked the creation of the Citizens' Committee in Port Arthur. Many at the meeting believed that the Port Arthur city council had essentially "turned over the reins of government to a soviet regime of patriotic citizens." Speaking on the situation, the mayor of Fort William assured Fort William residents that the mayor and council would be the authority and no one else. Murphy informed Manion and other federal and provincial officials of the meeting. "[T] he situation of affairs at the Head of the Lakes and West is evidently not fully understood by the Government and our Member," he argued. If drastic action were not taken and the situation in Winnipeg were to continue, "constitutional government in this part of the country [would be] endangered by thr [sic] powers of State and Civic Government 
being usurped by unauthorized bodies of citizens." Manion was also requested to return to deal with the local situation or to reflect the desire of his constituents and "make demands upon the Government on the floor of the House of Commons, that the cabinet cease to procrastinate, and at once take steps to show that they are not controlled by the great financial interests of the country."

Unwilling to criticize his own party, Manion informed Murphy that, contrary to what many believed, the government fully realized "the serious condition of affairs in Canada." What many saw as procrastination, he argued, was in fact a methodical process of deliberation to prevent anyone from taking "any hasty action which will interfere with that settlement...." As for demands that both he and the government resign, Manion retorted that, "with Canada in its present seriously unsettled condition the resignation of the government... would appear to me to be a calamity for we need a government now if we ever did." ${ }^{5}$ Manion addressed such questions as the rising cost of living and legal protection for collective bargaining by passing the buck to the provincial government. Such matters were "a provincial matter entirely," he argued. F.H. Keefer, M.P. for Port Arthur, agreed, and added for good measure that he was in favour of collective bargaining and shorter hours, but not "sovietism." 96

With the differences among the region's workers now aired, employers in the twin cities began to turn back to their old habits following the cessation of the Winnipeg General Strike. They began - to the disgust of Fred Moore of the Fort William Trades and Labour Council—-to collude in blacklisting suspect workers. The Council also argued that employers were targeting workers injured on the job. In response, it called for its members to organize and "combat such high-handed treatment of members of our class." ${ }^{\prime 7}$ Local trades and labor officials began to backpedal on their position taken during the strike. While not joining their voice with those workers led by Bryan, they did begin to voice opposition to the actions taken against the leaders of the Winnipeg strike following its cessation. In a separate statement to the press, while carefully distancing themselves from Bryan and "socialists," they did demand that the eight imprisoned Winnipeg strike leaders be released. However, they stopped short of the statement by Bryan and local Finns labour leaders that a Dominion-wide strike should occur if authorities refused to release the men. ${ }^{98}$ Workers in Fort William clearly remained divided. Little is known about the thoughts of Port Arthur workers. Meetings by some unions and representatives from socialist organizations did result in a similar resolution after speeches by Herbert Barker, James Dunbar and others were heard. ${ }^{99}$

\section{Conclusion}

Thus, the Lakehead was afire in 1919. Dissatisfied with the Conservatives, many called for radical change. Like many in Ontario, residents of the Lakehead took 
out their frustrations over high prices and the Hearst government's seeming indifference by electing former local locomotive engineer Harry Mills who represented Fort William in the coalition government formed by E.C. Drury in October 1919. ${ }^{100}$ A long-time member of the board of education, Mills' nomination came to many as something of a surprise. ${ }^{101}$ Alderman A.H. Dennis, a high profile member of the council and the Dominion Labour Party, W.N. Welsh, president of the Fort William Trades and Labour Council, and A.C. Stewart, a recently-arrived newcomer but highly popular rhetorician, had all reputedly sought the nomination. Even the Fort William Daily Times-Journal commented that Mills was not very well known amongst the rank-and-file of labour and his participation in the activities of the local labour council had been spotty, despite his presence within the city. However, both organized labour and former members of the Social Democratic Party of Canada (such as J. Dixon) in both cities rallied around Mills. ${ }^{102}$

On the day of the election, solidarity won, and Mills was elected to office with a majority of over 1700 in the city (although he faired less well in the rural areas). ${ }^{103}$ His nomination and election no doubt resulted from the wider base of support and appeal to former Lib-Lab supporters. Mills was unique, as it appears he was the only member of the Drury Government who had been the candidate of a Labour Council. ${ }^{104}$ Upon the recommendation of fellow Northern Ontario labour MPP Peter Heenan (himself recently elected in the Kenora riding) and in recognition of the Independent Labour Party's support of the United Farmers of Ontario, he was appointed Minister of the newly-created Department of Mines. ${ }^{105}$ Mills's success was the beginning of a series of electoral breakthroughs for organized labour in the twin cities. At the municipal level, the ILP ran candidates in both cities for a wide range of civic positions. ${ }^{106}$ Longtime councilor A.H. Dennis was elected as mayor in Fort William, replacing Murphy. Many felt a crucial issue in his rise to power was the latter's handling of the Winnipeg situation. ${ }^{107}$ In Port Arthur, Sid Wilson, an army veteran, Social Democratic Party of Canada member, and outspoken critic of the local newspaper's coverage of the Winnipeg General Strike, was reelected as ILP candidate to the city council. ${ }^{108} \mathrm{He}$, along with James Dunbar of the United Brotherhood of Carpenters and Joiners, represented the interests of organized trade union workers.

Thus, the ultimate beneficiaries of Lakehead's subdued "labour revolt" of 1919 were the labour centrists-the craft unionists, Lib-Lab supporters, and city councilors distrustful of both the Unionist government and the Winnipeg radicals. As one such centrist proclaimed, Lakehead workers had shown "more common sense" than the "ultra-radicals" of Winnipeg. Such labour centrists were generally Anglos who often disparaged political intransigence as the vice of foreigners. While the Winnipeg Strike may have in fact occurred in light of a referendum by the local trades council, to those who dominated the labour councils at the Lakehead in 1919, it served their purpose to exacerbate a public and government fueled position that radicals had somehow become ascendant within Winnipeg. ${ }^{109}$ 
A situation to be feared in Port Arthur and Fort William. However, the succeeding decades would reveal that these centrists, although powerful in their own circles, could not contain the more polarized class politics that emerged in the wake of Winnipeg. While the significance and role of the Winnipeg General Strike during this period will no doubt continue to be debated by scholars, it deeply influenced the reaction of the state to labour unrest that occurred in the subsequent years. ${ }^{110}$ As Merrily Weisbord writes, "For the Canadian government, the Winnipeg General Strike brought the bogeyman of the Russian Revolution home to roost." "111 Similarly, despite the Strike merely being part of a much larger movement of unrest, it too became a rallying point for socialists and their organizations in the post-war years at the Lakeheaad and beyond.

1 The Winnipeg General Strike has been the focus of numerous studies, plays, and films. Especially useful are David Jay Bercuson, Confrontation at Winnipeg rev. ed. (Montreal and Kingston: McGill-Queen's University Press, 1990); Gerald Friesen, "Yours in Revolt': The Socialist Party of Canada and the Western Labour Movement," Labour/Le Travailleur 1 (1976): 139-157; Harry and Mildred Gutkin, Profiles in Dissent: The Shaping of Radical Thought in the Canadian West (Edmonton: NeWest Press, 1997); Gregory S. Kealey, "1919: The Canadian Labour Revolt," Labour/Le Travail 13 (1984): 11-44; D.C. Masters, The Winnipeg General Strike (Toronto: University of Toronto Press, 1950); Kenneth McNaught and David J. Bercuson, The Winnipeg Strike: 1919 (Don Mills, Ontario: Longman Canada Limited, 1974); and Norman Penner, ed. Winnipeg 1919: The Strikers' Own History of the Winnipeg General Strike, $2^{\text {nd }}$ ed. (Toronto: James Lorimer \& Company, 1975).

2 Masters, The Winnipeg General Strike, ix.

3 Craig Heron, "Introduction," in The Workers' Revolt in Canada, 1917-1925, ed. Craig Heron (Toronto: University of Toronto Press, 1998), 7.

4 Ibid, 8.

5 For more on western radicalism, see A. Ross McCormack's classic study Reformers, Rebels, and Revolutionaries: The Western Canadian Radical Movement, 1899-1919 (Toronto: University of Toronto Press, 1977). In the 1920s, studies only include the Lakehead when dealing with the lumber industry. See, for example, Ian Radforth, Bushworkers and Bosses: Logging in Northern Ontario, 1900-1980 (Toronto: University of Toronto Press, 1987).

6 Bercuson, for example, describes the workers at the Lakehead as "perhaps the most militant in the country." See Fools and Wise Men: The Rise and Fall of the One Big Union (Toronto: McGraw-Hill Ryerson Limited, 1978), 42. For an extensive overview of the period before 1919 and for discussion of the tensions between trade unions, nonindustrial unions, and socialists, see Michel S. Beaulieu, “"'A Proletarian Prometheus: Socialism, Ethnicity, and Revolution at the Lakehead, 1900-1935" (Ph.D. diss., Queen's University, 2007). For more on labour at the Lakehead before 1914, see Jean Morrison, "Community and Conflict: A Study of the Working Class and Its Relationship at the Canadian Lakehead, 1903-1913” (MA thesis, Lakehead University, 
1974); "Ethnicity and Class Consciousness: British Finnish and South European Workers at the Canadian Lakehead Before World War 1," The Lakehead University Review 9:1 (1976): 55-65; "Labour in Fort William and Port Arthur, 1903-1913," Thunder Bay Historical Museum Society Papers and Records 1 (1973): 23-30.

7 For more on Labourism, see Craig Heron, "Labourism and the Canadian Working Class," Labour/Le Travailleur 13 (Spring 1984): 45-76.

8 See Jean Morrison, "The Organization of Labour at Thunder Bay." The United Brotherhood of Railway Employees were crushed between Winnipeg and Port Arthur following the suppression of UBRE-led strikes in 1902.

9 A.W. Rasporich, "Faction and Class in Modern Lakehead Politics," Lakehead University Review 7:1 (Summer 1974): 39.

10 See Martin Robin, Radical Politics and Canadian Labour, 1880-1930 (Kingston: Industrial Relations Centre, 1968), 79-91. This notion is shared in the work of Craig Heron. See, for example, The Canadian Labour Movement: A Short History (Toronto: James Lorimer and Company, 1989), 47.

11 Heron, The Canadian Labour Movement, 47. For more on the peculiarities of the Lakehead during this period, see Beaulieu, "A Proletarian Prometheus: Socialism, Ethnicity, and Revolution at the Lakehead, 1900-1935," 34-85.

12 For an overview of Harry Bryan, see Michel S. Beaulieu and Bruce W. Muirhead, "Harry Bryan - A Man of Fanatical Convictions," in Essays in Northwestern Ontario Working Class History, ed. Michel S. Beaulieu (Thunder Bay: Lakehead University Centre for Northern Studies, 2008).

13 See Jean Morrison, "Frederick Urry, Architect: The Wage-Earner's Advocate," Thunder Bay Historical Museum Society Papers and Records 14 (1986): 11.

14 Morrison, "Community and Conflict," 84.

15 Industrial Banner (September 1909). In one notable half-hour incident, CPR police were driven back and captured, with eight known casualties occurring. See FWDTJ, 13 August 1909. For more on the relationship between violence and labour struggles see Irving Abella, ed. On Strike: Six Key Labour Struggles in Canada 1919-1949 (Toronto: James Lormier and Company, 1975) and, specifically about the Lakehead, Morrison, "Community in Conflict" and "Ethnicity and Violence: The Lakehead Freight Handlers Before World War I."

16 See Western Clarion, 30 November 1907.

17 Jean Morrison, "The Organization of Labour at Thunder Bay," in Thunder Bay: From Rivalry to Unity, ed. Thorold J. Tronrud and A. Ernest Epp (Thunder Bay: Thunder Bay Historical Museum Society, 1995), 122. The United Brotherhood of Railway Employees were crushed between Winnipeg and Port Arthur following the suppression of UBRE-led strikes in 1902. For more on the topic of early unions, see Lakehead University Archives (hereafter LUA), Thunder Bay Finnish Canadian Historical Society, 1870-1970 (hereafter TBFCHS), B, 7, 30, Item 2, Tape 4, Interview with Einar Nordstrom, 15 and 19 March, 2 April, 7 May 1979. For more on the role of the Finns, see Radforth, Bushworkers and Bosses and Varpu Lindström, Defiant Sisters: A Social History of Finnish Immigrant Women in Canada, 2nd ed. (Beaverton: Aspasia Books, 2003). For more on Italians at the Lakehead, see see John Potestio, The Italians of Thunder Bay (Thunder Bay: Lakehead University, Chair of Italian Studies, 2005) and Antonio Pucci, “Thunder Bay's Two Little Italies: 1880-1940s," Polyphony 9:2 (1987): 
51-59.

18 Desmond Morton (with Terry Copp), Working People: An Illustrated History of Canadian Labour (Ottawa: Deneau and Greenburg Publishers Limited, 1980), 111.

19 Ibid., 102.

20 Roy MacLaren, Canadians in Russia, 1918-1919 (Toronto: Macmillan Company of Canada Limited, 1976), 7.

21 For more on the Red Scare, see Donald Avery, 'Dangerous Foreigners': European Immigrant Workers and Labour Radicalism in Canada, 1896-1932 (Toronto: McClelland and Stewart Ltd., 1979) and Avery, Reluctant Host: Canada's Response to Immigrant Workers, 1896-1994 (Toronto: McClelland and Stewart, 1995). While somewhat dated, the most thorough studies to date on the Canadian press response to the events in Russia between 1917 and 1919 are Theresa Catherine Baxter, "Selected Aspects of Canadian Public Opinion on the Russian Revolution and on its Impact in Canada, 1917-1919” (MA thesis, The University of Western Ontario, 1972) and Elliot Samuels, "The Red Scare in Ontario: The Reaction of the Ontario Press to the Internal and External Threat of Bolshevism, 1917-1919" (MA thesis, Queen's University, 1971).

22 Fort William Daily Times-Journal (hereafter FWDTJ), 9 April 1919.

23 FWDTJ, 8 April 1919.

24 See, for example, FWDTJ, 5 May 1919; Port Arthur News-Chronicle (hereafter PANC), 15 April 1919; 16 April 1919.

25 This concern is reflected in the number of files listed in the RCMP Personal Files Register and Subject Files Register for 1919. See Gregory S. Kealey and Reg Whitaker, eds. R.C.M.P. Security Bulletins: The Early Years, 1919-1929 (St. John's: Canadian Committee on Labour History, 1994), 383-651.

26 PADNC, 26 November 1917.

27 TBA, FWF, FWCC, 5, File 148. F.H. Bole, Mutual Elevator Co. Ltd. to Fort William City Clerk, 5 October 1917.

28 PADNC and FWDTJ 1 October 1917; 2 October 1917; and 6 October 1917.

29 PANC, 30 April 1919.

30 FWDTJ, 12 April 1919; House of Commons, Debates, 12 May 1919, p. 2325; and Roy Piovesana, Robert J, Manion: Member of Parliament for Fort William, 1917-1935 (Thunder Bay: Thunder Bay Historical Museum Society, 1990), 19 and 23. The Fort William unit was dismantled shortly after the end of the Winnipeg General Strike.

31 PANC, 13 May 1919.

32 PANC, 14 May 1919.

33 FWDTJ, 15 April 1919.

34 PANC, 14 May 1919. For more on Urry, see Jean Morrison, "“Frederick Urry, Architect: The Wage-Earner's Advocate," Thunder Bay Historical Museum Society Papers and Records XIV (1986): 8-22.

35 FWDTJ, 14 March 1908.

36 Morrison, "Frederick Urry, Architect: The Wage-Earner's Advocate," 11.

37 United Church of Canada Archives, "Minutes of the Board of Moral and Social Reform," 9 September 1908 cited in Morrison, "Frederick Urry, Architect: The WageEarner's Advocate," 8. Fn 1, 21.

38 Western Clarion, 26 September 1908 and Morrison, "Frederick Urry, Architect: The 
Wage-Earner's Advocate," 8.

39 Leo T. English quoted in Morrison, "Labour in Fort William and Port Arthur, 19031913," 28. See also PADN and FWDTJ 5 April 1908

40 FWDTJ, 7 May 1919. Often connections between Ukrainians and Russians were within the context of military alliances and political intrigue. See, for example, FWDTJ, 5 May 1919.

41 See FWDTJ and PANC, 7 May to 14 May 1919.

42 FWDTJ, 15 May 1919.

43 FWDTJ, 16 and 17 May 1919.

44 PANC, 16 May 1919.

45 FWDTJ, 21 May 1919. For a discussion of the second week of the strike as the launch of a crucial period, see McNaught and Bercuson, The Winnipeg General Strike: 1919, 62-85.

46 See see LUA, Jean Morrison Labour History Collection (hereafter JMLHC), General Series 186a, Tape 5, Harry Bryan Reminiscences, 1972.

47 LUA, Canadian Teollisuusunionistinen Kannatus Liito fonds (hereafter CTKL), MG10, Series D, 8, 10, “A.T. Hill Biography,” nd., p. 12.

48 FWDTJ and PANC, 29 May 1919.

49 City of Thunder Bay Archives (hereafter TBA), Fort William fonds (hereafter FWF), Series 4: City Clerks Files (hereafter FWCC), 5, File 148, Fred E. Moore, Secretary, Trades and Labour Council to Mayor Murphy, Fort William 30 May 1919 and FWDTJ, 30 May 1919.

50 FWDTJ, 26 May 1919.

51 PANC, 28 May 1919.

52 The Fort William City Clerk was informed by the Mayor of Kenora on 17 May that the express handlers of the railway depot had walked off the job in support of those in Winnipeg. See FWDTJ, 17 May 1919.

53 The 19 May 1919 issue of the FWDTJ contains an article describing this "peculiar feature" of the Winnipeg strike.

54 FWDTJ, 30 May 1919.

55 See FWDTJ, 19 May 1919.

56 For an example of the type of coverage given see PADNC, 17 May 1918.

57 PANC, 28 May 1919.

58 Library and Archives of Canada (hereafter LAC), Department of Labour fonds (hereafter DL), RG27, vol. 313, strike 136, Frederick Urry to F.A. Acland, 15 and 19 May 1919; PANC, 19 May 1919; 21 May 1919; and FWDTJ, 19 May 1919. Newspaper articles from other parts of the country also reiterated this claim. See, for example, Saskatoon Phoenix, 29 May 1919; Toronto Globe, 21 May 1919; and Montreal Star, 21 May 1919.

59 PANC, 21 May 1919.

60 Crafts affected included, according to newspapers reports, 100 Machinists; 700 helpers, laborers, riveters, and bolters; 90 carpenters; 25 painters; 75 riggers; 40 blacksmiths; 45 electricians; 15 pattern makers; 60 moulders'; 25 boilermakers; 100 scaffoldmen; and 25 lathemen. Grant, for example, stated to the Fort William Daily TimesJournal that by going on strike it might "be the means of getting the government to see what it means to have all this striking throughout the country." FWDTJ, 19 May 
1919. For coverage of the strike, see PANC, 13 and 19 May 1919.

61 FWDTJ, 26 May 1919.

62 FWDTJ, 19 May 1919. Grant, for example, stated to the Fort William Daily TimesJournal that by going on strike it might "be the means of getting the government to see what it means to have all this striking throughout the country." This same quote is included in footnote 60 .

63 FWDTJ, 22 May 1919.

64 PANC, 21 May 1919; 3 June 1919; 5 June 1919; FWDTJ, 3 June 1919; 4 June 1919; 7 June 1919; 21 June 1919; Montreal Gazette, 9 June 1919; Toronto Globe, 4 June 1919; Toronto Star, 4 June 1919; and Ottawa Citizen, 4 June 1919. While the strike technically lasted until 25 June, workers actually had gone back to work fifteen days earlier and both the unions involved and company officials stressed publicly throughout that strike that negotiations continued unabated.

65 PANC, 22 May 1919.

66 LAC, DL, vol. 313, strike 135, Frederick Urry to F.A. Acland, Deputy Minister of Labour, 31 May 1919 and $P A N C, 27$ May 1919.

67 TBA, FWF, FWCC, 5, File 148, Telegram, G.D. Robertson to H. Murphy, 29 May 1919; FWDTJ, 29 May 1919; and PANC, 29 May 1919.

68 TBA, FWF, FWCC, 5, File 148, H. Murphy to Fred E. Moore, Secretary, Trades and Labour Council, 29 May 1919.

69 TBA, FWF, FWCC, 5, File 148, Fred E. Moore, Secretary, Trades and Labour Council to Mayor Murphy, Fort William 30 May 1919 and FWDTJ, 30 May 1919.

70 FWDTJ, 30 May 1919.

71 The first announcement of this organization came in the 20 May 1919 issue of the FWDTJ.

72 Morrison, "The Organization of Labour at Thunder Bay," 129. See also PANC, 20 June 1919. The Provisional Organizer of the League was C. Birkett.

73 FWDTJ, 30 May 1919.

74 PANC, 3 June 1919 and FWDTJ, 3 June 1919.

75 The editor of the Fort William Daily Times-Journal also supported the notion that both the Fort William and Port Arthur City Councils would be able to maintain the law.

76 FWDTJ, 3 June 1919.

$77 \quad P A N C$ and FWDTJ, 3 June 1919.

78 FWDTJ, 3 June 1919.

79 FWDTJ, 3 June 1919.

80 FWDTJ, 2 June 1919. Unfortunately, after a thorough exploration, I have been unable so far to obtain figures as to the total number of workers involved in these unions.

81 For more on the position of the running trades in western Canada, see Tom Mitchell and James Naylor, "The Prairies: In the Eye of the Storm," in The Workers' Revolt in Canada, 1917-1925, 208-210.

82 Mitchell and Naylor, "The Prairies: In the Eye of the Storm," 199.

83 PADNC and FWDTJ, 4 June 1919.

84 PANC, 4 June 1919.

85 FWDTJ, 10 June 1919.

86 Morrison, "The Organization of Labour at Thunder Bay," 129.

87 FWDTJ, 4 and 6 June 1919. Following the announcement, the mayor of Fort William 
immediately banned all forms of parade and large gathering.

88 FWDTJ, 31 May 1919.

89 See minutes for 1919 in LAC, Finnish Association (Suomalainen Osasto) of Port Arthur fonds, MG28-V137. The author would like to thank Samira Saramo of York University for her translation of this material.

90 LAC, DL, vol. 313, strike 136 and PANC, 22 May 1919. Although it is not known if the Port Arthur Branch of the Great War Veteran's Association met or attempted to meet with representatives of that city's Trades and Labour Council, they did hold a similar position as their Fort William counterparts.

91 FWDTJ, 6 June 1919. The Fort William Great War Veterans Association was represented by Douglas Kerr. He had originally referred to the committee and the "strike committee," but, following an objection by W.N. Welsh, he corrected himself and referred to them as "labour leaders."

92 FWDTJ, 6 June 1919.

93 FWDTJ, 6 June 1919.

94 LAC, Robert Borden fonds, MG26-H, vol. 113, Harry Murphy to Robert Borden, 6 June 1919; TBA, FWF, FWCC, 5, File 148, Harry Murphy to Robert Borden, 6 June 1919; TBA 5, File 148, Harry Murphy to Sir. Robert L. Borden, Dr. R.J. Manion, and Mr. F.H. Keefer, 6 June 1919; and FWDTJ, 6 June 1919.

95 TBA, FWF, FWCC, 5, File 148, Telegram, R.J. Manion to H. Murphy, 6 June 1919 and FWDTJ, 7 June 1919.

96 TBA, FWF, FWCC, 5, File 148, Telegram, F.H. Keefer to H. Murphy, 7 June 1919. Keefer had long believed that certain areas of the country - namely the Lakehead were "breeding places of revolution" and should be dealt with severely. See PANC, 1 May 1919.

97 Archives of Ontario (hereafter AO), Fred E. Moore fonds (hereafter FEM), MV 2160, F 1284, “Trades and Labour Council Bulletin," Fort William, 28 July 1919.

98 FWDTJ, 6 and 8 September 1919.

99 PADNC, 8 September 1919.

100 For more on the Southern Ontario electoral response, see James Naylor, "Southern Ontario: Striking at the Ballot Box" in Heron, The Workers' Revolt in Canada, 19171925, 144-175. For overviews, see Peter A. Baskerville, Sites of Power: A Concise History of Ontario (Toronto: Oxford University Press, 2005), 183-192; Joseph Schull, Ontario Since 1867 (Toronto: McClelland and Stewart, 1978), 235-257. Some scholars have argued that the election of the United Farmers, and the role of labour in the Drury government, was foreshadowed by the 1918 Manitoulin By-Election. See FJ.K. Griezic, "Power and the People. The Manitoulin By-Election, October 24, 1918," Ontario History LXIX:1 (March 1977): 33-54.

101 Despite being a surprise, the nomination meeting featured a who's who of local socialists and labor representatives. Speaker's featured M. Welsh, H. Barker, Alderman Sid Wilson, who were joined by Harry Bryan, now living in the town of Dorion located $100 \mathrm{~km}$ away, now representing the United Farmers of Dorion Township. See PADNC, 16 September 1919.

102 FWDTJ, 27 September and 4 October 1919; PADNC, 1 and 3 October 1919. See also Martin Robin, Radical Politics and Canadian Labour, 1880-1930 (Kingston: Industrial Relations Centre, Queen's University, 1968), 223. The Daily Times-Journal 
attributed his absence from the Trades and Labour Council to his dedication to his board of education duties. Mills received support also from the Woman's Labour League in Fort William. His wife, a member, spoke of "Votes for Women." See FWDTJ, 11 October 1919.

103 PADNC, 21 October 1919.

104 Industrial Banner, 24 October 1919 and Jean Morrison, "The Organization of Labour at Thunder Bay," 129. For more on the election of the United Farmers and their relationship with independent labour, see James Naylor, The New Democracy: Challenging the Social Order in Industrial Ontario, 1914-25 (Toronto: University of Toronto Press, 1991), 121-4, 218 and 222-225.

105 Robin, Radical Politics and Canadian Labour, 226-227.

106 PADNC, 30 October 1919.

107 Murphy's role in settling the Coal Dock Worker's Strike received national attention. See, for instance, Montreal Star, 25 June 1919 and Toronto Globe, 25 June 1919.

108 A branch of the Dominion Labour Party had been established in Port Arthur specifically for the municipal election. Rod Young ran for mayor, Sid Wilson, Jas. Dubar, and J.B. McArthur for aldermen. Sam Wright and George Bell ran for utilities and J. Robertson and J. Faithful for trustees. See FWDTJ, 1 and 8 November 1919.

109 For more on Labourism in Winnipeg, see McCormack, Reformers, Rebels, and Revolutionaries.

110 The Winnipeg General Strike has been the focus of numerous studies, plays, and films. Especially useful are David Jay Bercuson, Confrontation at Winnipeg rev. ed. (Montreal and Kingston: McGill-Queen's University Press, 1990); Gerald Friesen, "Yours in Revolt': The Socialist Party of Canada and the Western Labour Movement," Labour/Le Travailleur 1 (1976): 139-157; Harry and Mildred Gutkin, Profiles in Dissent: The Shaping of Radical Thought in the Canadian West (Edmonton: NeWest Press, 1997); Gregory S. Kealey, “1919: The Canadian Labour Revolt," Labour/Le Travail 13 (1984): 11-44; D.C. Masters, The Winnipeg General Strike (Toronto: University of Toronto Press, 1950); Kenneth McNaught and David J. Bercuson, The Winnipeg Strike: 1919 (Don Mills, Ontario: Longman Canada Limited, 1974); and Norman Penner, ed. Winnipeg 1919: The Strikers' Own History of the Winnipeg General Strike, 2nd ed. (Toronto: James Lorimer \& Company, 1975).

111 Merrily Weisbord, The Strangest Dream: Canadian Communists, the Spy Trials, and the Cold War (Montréal: Véhicule Press, 1983, reprint 1994), 27. While this opinion was shared by most of the media, the work of Michael Dupuis argues that the Toronto Star was more moderate in its assessment. See Dupuis, "The Response of the Toronto Daily Press to the Winnipeg General Strike" (MA thesis, University of Ottawa, 1973) and "Winnipeg's Red Scare," The Beaver 